\title{
Research on the Subject Status and Leading Role of the Enterprises Technological Innovation in the Overall Innovation
}

\author{
Shushan ZHAO* \\ City College of Dongguan University of Technology, P.R.China, 523410 \\ e-mail: nytczss@163.com \\ *Corresponding author
}

\begin{abstract}
The enterprises technological innovation is the core to implement the innovation driven strategy and to realize the overall innovation. It is necessary to establish the subject status of the enterprises technological innovation and to play fully its leading role. It is necessary to cultivate the independent innovation ability of the enterprises and to realize the leaping breakthrough, especially to promote the enterprises technological innovation and enhance the international competitiveness by the way of the system innovation.
\end{abstract}

Keywords-Technological innovation, Core technology, Subject status, Leading role, System innovation, Enterprise

\section{INTRODUCTION}

By reviewing the development of the world economy, we may find the motive power behind its development is just the innovation. The continuous development of the economy can be guaranteed on if the innovation continuously emerges. Since the Eighteenth Congress of the Chinese Communist Party, Chinese President Xi Jinping has stressed repeatedly to place the technological innovation in a more important position. In order to implement the innovation-driven strategy and to realize the technological innovation, we must first play the role of the enterprises technological innovation and breed its leading role in the overall innovation.

\section{THE KEY OF THE OVERALL INNOVATION IS THE TECHNOLOGICAL INNOVATION}

The concept "Innovation" is proposed first by the economist of Schumpeter. Its original meaning is to introduce the new combination of production factors to the economy, that is to say, to establish a new production function. The reason that Schumpeter proposes the concept and theory of innovation is to try to explain the economic development by using this concept. The economy development is different from the economic growth. The economic development means the establishment of the new production function and the formation of the new production methods, while this new technology and new organization mode are substantially the results of the innovation. After the Second World War, the research on the innovation gradually becomes one important field in the economics and sociological research, the concept and theory of innovation have expanded much and formed the innovation concept of broad sense and the innovation concept of narrow sense. The concept of total innovation management is formed on the base of the innovation concept of broad sense.
The total innovation management is by far the most advanced and scientific innovation management model. It takes the building and improvement of the core ability as the center, takes the creation and increase of the value as the objective, takes the strategy as the direction, takes the technological innovation as the core, takes the organic combination of the various innovation and collaborative innovation as the measure. It aims at realizing the innovation of everyone, everything, from time to time and everywhere by means of the effective system and method of the innovation management. From the concept of the total innovation management, the core of the innovation is the technological innovation. In order to realize the more reasonable resource utilization, the more harmonious and efficient operation of the enterprises and the social system and the more fully effective development of the productive power, the total innovation management, under certain technical conditions, is the development strategy, management system, organization structure, system and culture. [1]

In daily life, people are used to confusing invention with technological innovation and think the invention is just the technological innovation. Indeed, an invention may be one kind of original or improved equipment, product or process. It also may be one kind systemic idea, draft or model. But, the invention does not necessarily lead to technological innovation and in reality many inventions haven't turned into the technological innovation. According to the economics theory, the technological innovation is completed until the first commercial application of the new product, supply and demand system and equipment is realized. So, if one invention hasn't been applied in the production system, it cannot be regarded as technological innovation. Only if the invention has realized its first commercial application, it can be become the technological innovation. For example, Watt invents the steam engine and later Watt and Bolton open a factory together to manufacture and sale the steam engine. That is the real technological innovation.

On the seventh meeting of the central financial and economic leading group on August 18, 2014, Chinese President Xi Jinping has pointed clearly: "The implement of the innovation driven strategy proposed on the Eighteenth Congress of the Chinese Communist Party is just to push forward the overall innovation which takes the technological innovation as the core, to insist the demand orientation and industry orientation, to insist the subject status of the enterprise in the innovation, to play the decisive effect of the market in the distribution of resources and the advantages of the socialist system, to 
enhance the contribution degree of the scientific and technological advance in the economic growth, to form the new growth momentum source and to promote economic development continuously, steadily and healthily." The whole Party and the whole nation must unify their thinking and raise effectively awareness. In order to manifest the subject status of the technological innovation, Chinese President Xi Jinping compares picturesquely the technological to grasping the key link. When inspecting in Shanghai on May 23-24, 2014, Chinese President Xi Jinping points: in today's world, the one, who grasps the key link of the technological innovation and who takes the offensive move of the technological innovation, can occupy the decisive occasion and win the advantages. So, in the process of implement of the overall innovation strategy, we must pay high attention to the status and role of the technological innovation, and place the technological innovation in the most important position in the overall innovation.

\section{ENTERPRISE IS THE CORE SUBJECT OF THE TECHNOLOGICAL INNOVATION}

Subject is the undertaker of the practical activity and the subject of innovation is such person or social organization that has innovation ability and is actually engaged in innovation activities. The innovation is the unique human activities and it is the motile creative activities done by human. It is one basic feature with which the human becomes the intelligent part of the universe. But according to the innovation theory, generally speaking, the innovation subject should satisfy the following four features: 1) the innovation subject has the decision-making authority of the innovation activities; 2) the innovation subject has the ability to carry out the innovation activities; 3) the innovation subject undertakes the responsibilities and risks of the innovation activities; 4) the innovation subject obtains the profit of the innovation activities. [2] According to these four features, the university, scientific research institutes, entrepreneurs and enterprise can become the innovation subject. This is a diversified concept.

But in the concept of multi-agent innovation, the enterprise is the core subject. If we interpret the scientific research and the technological innovation as three kinds of activities of basic research, application research and experimental development, we can make out that the enterprise is biased towards the experimental development while the university and scientific research institutes are biased towards the basic research and application research. But in the actual practice, the basic research and the scientific research are not simply linear with the experimental development. That is to say, the scientific research does not certainly lead to the technological innovation. The scientific research will really turn into the technological innovation until the enterprise is brave in using the results of the scientific research to the experimental development and adopting the results of the outside science and technology and the innovation. Just as Chinese President Xi Jinping says, the technological innovation is to break through the core technology and to seize the commanding elevation of science and technology. He says that only mastering the core technology in our own hands can really master the initiative of the competition and development and can fundamentally safeguard the national economic security, national defense security and other security.

So, for the technological innovation and its spread, in the light of the concept of the technological innovation, the enterprise is the core subject of both the technological innovation in the broader sense and the technological innovation in the narrow sense. The enterprise is the only source of adopting the results of the science and technology. About this, when Deng Xiaoping analyzes the scientific and technical structural reform, he has pointed out that the key is to establish the subject status of the enterprise in the scientific and technological advance in order to transform the science and technology into realistic productivity and to make the economic construction depend on the scientific and technological advance. The reform of the economic system and the scientific and technological system aims at liberating the productive forces. The new economic system should be such system that benefits the technological advance. The new scientific and technological system should be such system that benefits the economic development. The long-standing problem that the scientific and technological system and the economic system are disjointed can be settled well. The center task of promoting the combination of science and technology and economy is to establish the technology innovation system which takes the enterprise as the main body, be market-oriented and combines production, study and research. Under the condition of market economy, the enterprise has irreplaceable status and role in the technology innovation. Only the enterprise is taken as the subject, the market-oriented of the technology innovation can be insisted and the power of the production, study and research can be effectively integrated. [3]

Taking the enterprise as subject means that the enterprise should become not only the subject of the technology innovation input, but also the subject of research and development, the subject of scientific and technological achievements application and the subject of undertaking the profit and loss of technological innovation. Just as Chinese President Xi Jinping points out the forum on network security and informatization on April 19, 2016, "we should encourage and support the enterprise to be the subject of the research and development, the subject of innovation and the subject of industry, encourage and support the enterprise to do the layout of the front technology, to promote the self-dependent innovation of the core technology, to create and grasp more opportunities, to participate in the international competition and to expand the overseas development space."

The subject status of the enterprise in the technological innovation must be highlighted and the leading role must be played. Firstly, the enterprise should become the investment subject of the technological innovation. Under the new situation of the innovation-driven and energy conversion, the enterprise, in line with the macro guide of the national industrial policy and technology policy and the actual situation of 
the market demand and the competition, need select independently and carry out the technological innovation programs corresponding to its actual strength and development goal, increase the investment, carry out effective technological innovation and undertake the corresponding investment risk. Secondly, the enterprise should become the subject of the research and development. The enterprise need to train and introduce the technology innovation and development talent, to establish the situation research institution consistent with the research and development or cooperate with the scientific research institution and higher learning institutions to establish the collaborative innovation base. The enterprise need innovate the new system and mechanism and carry out the research and development by way of the effective inspiriting mechanism. Thirdly, the enterprise should conscientiously become the subject of undertaking the profit and loss of the technological innovation. The uncertainty and high risk of technological innovation make the technological innovation face at any time the risk of failure. The enterprise is not only the beneficiary of the innovation achievements, but also the undertaker of the loss. It is the root of the internal incentive and restricted factors of the enterprise playing their role and the necessary requirements of the enterprise becoming the subject of innovation investment and research and development that the enterprise becomes the undertaker of the innovation profits and losses.

\section{STRENGTHENING THE ENTERPRISE'S} INDEPENDENT TECHNOLOGICAL INNOVATION

All the countries are open to each other in today's world. Especially the continuous advance of the globalization has changed the past self-sufficient and closed state of the nations and states. The nations and states in the world system have gradually formed increasingly profound and various interrelation interdependence and the international communication of the economy and science and technology is more common. But, the constantly strengthened interdependence among the nations and states hasn't changed the essence of competition among them. Knowledge and technology are becoming important resources that decide the competitive advantage. Since 1980s, the developed countries have been consolidating constantly their advantaged status in the international competition by means of the globalized intellectual property system. "Control by means of technology" has gradually become the key method used by the developed countries to improve the comprehensive competitiveness of the state in the international competition. This institutional arrangement of the developed countries, on one hand, makes the post development countries with relatively backward economy and science and technology face the higher learning cost and hardly gain the core technology and knowledge by import; on the other hand, this institutional arrangement decides that if the post development countries still stay at the level of imitation and tracking, they will be in a passive position in the knowledgeable global competition.
So, to introduce the technology doesn't equal to introduce the technological innovation ability. Experience has proved that the real core technology cannot be gained by introduction of the technology. The technological innovation is endogenous and it only can be gained by the organized learning and the practice of the technology product development. If China wants to master the initiative in the fierce international competition, it must improve the ability of independent innovation, master a large number of core technology in several important areas, have a large number of independent intellectual property right and create a number of enterprises with international competitiveness. Just as Chinese President Xi Jinping stresses, "Only mastering the core technology in our own hands can really master the initiative of the competition and development and can fundamentally safeguard the national economic security, national defense security and other security. We cannot usually dress up our tomorrow by using yesterday of others. We cannot usually expect to depend on the scientific and technological achievements of others to improve our level of science and technology. We cannot be technology vassal of other countries and always follows the footsteps of others. [4]

The independent innovation is, from the national innovation ability, to enhance the original innovation, integrated innovation and absorbant innovation, to centralize strength, to leap forward prominently and to continuously improve the core competitiveness. The enterprises must manage:1) Focus on training the entrepreneur's creative spirit and make them be good at innovation; 2) Increase investment in scientific and technological innovation and lay the foundation for innovation. 3) Cultivate the innovative talents. 4) Realize the collaborative innovation by using the innovation resources of scientific research institutes. The collaborative innovation is the most effective way. By using the external resources and taking the road of cooperative innovation and collaborative innovation, the Network innovation model will be formed which is the collaborative interactive model of the multiple subjects, including the core subjects of universities, enterprises and scientific research institutions and the auxiliary subjects of financial institution, intermediary organization and innovation platform. The nonlinear utility " $1+1+1>3$ " will be produced by the in-depth cooperation and resource integration between the knowledge creation subject and technology creation subject. [5]

\section{BREEDING THE TECHNOLOGICAL INNOVATION BY SYSTEM INNOVATION}

The technological innovation has the uncertainty and different degrees of risk. The function of the system is to reduce the costs and risks of the innovation by reducing the uncertainty and to guarantee the income maximization of the innovation subject in order to guarantee the maximization of innovation power. As to the technological innovation of the enterprises, the system innovation can reduce the uncertainty and transaction cost of the innovation and can provide the innovation encourage. Just as Knouss says: One efficient 
system can encourage labors to create more wealth, even if it hasn't advanced equipment or technology; on the other hand, the advanced equipment and technology, if in a low efficiency institutional environment, cannot contribute efficiently to economic growth. Under continuous conditions, the system innovation is more fundamental than the technological innovation. [6]

Hence one can see that any technological innovation is activities carrying on in one continuous kind of system arrangement and system structure. The technological innovation depends on the effective encourage of the system innovation, especially the compensation system of the innovator and the intellectual property protection of the innovation achievements. Just as Chinese President Xi Jinping has pointed out in his speech on November 17, 2012, the Eighteenth National Congress of the Communist Party of China stresses that the system construction must be placed in a prominent position and we should give full play to the superiority of socialist political system. We should adhere to promote the system innovation by theoretical innovation based on practice, insist on and improve the existing system, proceed from the actual situation, develop new systems in time, construct complete, scientific and standardized and effective system, make all the systems more mature and more case-hardened, and provide more effective system safeguard for winning the new victory of socialism with Chinese characteristics.

To realize the system innovation, firstly, we shall establish the subject status of the enterprises technological innovation, give full play to the leading role of enterprises independent innovation, improve the fiscal and tax, financial and technology import policies of encouraging and promoting the enterprises independent innovation, guide to establish the technology innovation system which takes the enterprise as the main body, be market-oriented and combines science, education and enterprises, guide the enterprises to strengthen original innovation ability and integrated innovation capability in the key areas. Secondly, we shall build actively a platform of collaborative innovation for the enterprises technological innovation, realize the innovation of the system and mechanism of science and technology, help the enterprises effectively integrate the innovation resource of the social science and technology and realize the leaping breakthrough of the innovation. Thirdly, we shall fully implement the innovation-driven development strategy, continuously activate the new kinetic energy of the innovation, form a perfect and consistent policy system of the technological innovation and promote the rapid transformation of scientific and technological achievements.

\section{REFERENCES}

[1] Zhong Ning, Innovation management: gaining continuous competitive edge [M]. Beijing: China Machine Press, 2013:27.

[2] National Engineering Master of Political Theory Teaching Materials Writing Group. Dialectics of nature-Theory and application in Engineering [M]. Beijing: Tsinghua University press, 2010:144-145.

[3] Speech at the National Conference on science and technology. See: Selected Works of Deng Xiaoping (Second volumes).

[4] Speech of General secretary Xi Jinping on the Forum on network security and information technology on April, 19, 2016[N]. Guangming Daily, April, 28, 2016: (1).

[5] Jin Chen. Collaborative innovation [M]. Hangzhou: Zhejiang University Press, 2012:29.

[6] D.C. North, R. P. Thomas, The rise of the western world [M]. Trans., Yining Li, Lei Cai. Beijing: Huaxia Press, 1999:5. 